\title{
SZÁJKOSÁR ÉS PÓRÁZ: KIÉ ITT A TÉR?*
}

\author{
Józsa Zoltán ${ }^{1}$
}

A Szeged Megyei Jogú Város Önkormányzata Közgyülésének 27/2016. (XI.16.) számú önkormányzati rendelete 2017. január 1-én lépett hatályba a közösségi együttélés alapvető szabályairól. A rendelet a Magyarország helyi önkormányzatairól szóló 2011. évi CLXXXIX. tv. 8. § (2) bekezdésében és a 143. § (4) bekezdés d, pontjában kapott felhatalmazás alapján új alapokra helyezte a közösségi együttélés szabályait a közel 170.000 lakosú megyei jogú városban, melyben a hozzávetőleges becslések szerint csaknem 13.000 kutya él.

A testület 2016 novemberi közgyülésének ezen napirendi pontját talán a többinél is élesebb reakciókkal fogadták, mind a városháza dísztermében helyet foglaló képviselők, mind pedig az utcán felvonuló, tiltakozó tüntetők.

A közösségi együttélés alapvető szabályairól szóló rendeletet Nagy Sándor városfejlesztési alpolgármester ismertette. A jogszabály nemcsak azt határozta meg, hogy mi minősül a közösségi együttélés alapvető szabályaival ellentétes magatartásnak, de definiálta a közterület fogalmát, szólt a közterület rendeltetéséről, a közhasznúnak minősülő zöldterületekről, s utoljára, de nem utolsó sorban rendelkezett arról is, hogy mi értendő eb futtatása alatt.

Kiemelte, hogy a város öt, idegenforgalmi szempontból is frekventált tere (Móra park, Széchenyi tér, Dugonics tér, Aradi vértanúk tere, Rerrich tér) kiemelt védelmet élvez. Szólt arról is, hogy Szeged közel 300 hektár zöldfelülettel rendelkezik, ennek 99 százalékán továbbra is lehet labdázni, piknikezni, szórakozni.

Eközben az Önkormányzat épülete előtti Széchenyi téren, civilek kisebb csoportja demonstrált a szabad közterekért, véleményének oly módon is hangot adva, hogy a tér szökőkútjainak oldalát tiltakozó feliratokkal látták el. Az opponálók kicsi, de annál hangosabb csoportját alkották az ebtulajdonosok, akik a kellő számú kutya futtató hiányát, s hasonlóan a többiekhez, a kiszabható bírságok $(5.000-200.000$ Ft) nagyságát sokallták.

Bent a képviselők szemantikai köntösbe bújtatott politikai vitája fütötte az indulatokat, furcsa kérdésekkel a középpontban: lehet-e zöldfelületen gördeszkázni? Mi minősül labdázásnak, ha elgurul egy labda, vagy ha a labdát a szülők odagurítják a gyereknek? Az érvek és ellenérvek amplitúdója helyenként a szélső értékeket is túllépte, mivel egyes képviselők a tervezet rendelkezéseiben a szabadságjogok korlátozását vélték felfedezni, melynek révén a város vegzálhatja a padon pihenő hajléktalanokat, $\mathrm{s}$ büntetheti a szökőkútban fürdőzőket, a szobrokra felkapaszkodó gyerekeket vagy turistákat.

Végül is nem kerülhető meg az alapkérdés: kié itt a tér? A profán és a természetes reakció, az azonnali válasz szinte mindannyiunk esetében azonos: a miénk itt a tér. Úgy, ahogy a hetvenes évek végén a legendás LGT slágere ${ }^{2}$ megfogalmazta:

\footnotetext{
${ }^{*}$ DOI 10.21867/KjK/2017.1.1.

${ }^{1}$ Dr. habil. Józsa Zoltán, egyetemi docens (SZTE-ÁJK)

${ }^{2} \mathrm{https} / / / \mathrm{www}$.youtube.com/watch? $\mathrm{v}=\mathrm{KDwKaQQT} 90 \mathrm{I}$
} 
Miénk itt a tér, mert mi nőttünk itt fel,

A ház is a miénk, mert mi viseljük el,

Nekünk kevés fény jut, árnyékból van több,

Sötét szobánkban a pók rossz hálót köt.

Egy generáció életérzése, hangja szólt a sorokból, azé a generációé, melynek szabadság utáni vágya, az önmegvalósítás igénye, a kitörés, népek, nemzetek, kultúrák, ideológiák, szokások megismerésének a lehetősége nem, vagy csak korlátozottan adatott meg, s gyakran még az a kevés is veszélybe került, ahol igazán otthon érezhette magát.

A tér akkoriban, mint a szabadság összeszükült szimbóluma keveset jelentett. A házat, a közeli teret, parkot, a közvetlen barátokat, minden olyat, amit nem lehetett elvenni, kisajátítani. Hiába volt a képletes szájkosár és póráz. A tér bevehetetlen volt, és az is maradt, ott mélyen, a lelkekben.

Azóta sok minden megváltozott. A tér új dimenziókat nyert, kitágult. Fizikai és átvitt értelemben egyaránt. A határok szinten korlátok nélkül átjárhatók, $\mathrm{s}$ ha ez nem elég, elektronikus sztrádán száguldhat a képzelet, újabb és újabb felfedezés, újabb és újabb ismeret tágítja a teret, $\mathrm{s}$ kapcsolhatja össze a korábban elérhetetlennek látszó pontokat.

Ma már a tér, s különösen a közterület közjószág, valamennyiünké, a szó legnemesebb és legtágabb értelmében. Ahogy a definíció ${ }^{3}$ is mondja, a közjószág olyan jószág, melynek fogyasztásából más fogyasztók nem zárhatók ki, de azok nem is zavarják a másik fogyasztót. A közjószág fenntartása, gondozása, állagának megóvása, gyarapítása közérdek. Ez még akkor is igaz, ha sokan természetes módon élvezik tereink jó levegöjét, a szökőkutak csobogását, a parkok, terek zöldellő fáit és bokrait, s nem gondolnak a környezetvédelem fontosságára, s még kevésbé az egyre növekvö környezetvédelmi kiadásokra.

Egy individuális, az egyént, az egyéni kezdeményezést, a sikert elismerö, s gyakran túlértékelő világban nem könnyü az egészséges egyensúlyt megtalálni az érdekek szövevényes hálójában. Különösen akkor nem, ha a politikai, társadalmi közbeszéd közösségi fókuszának ellenére a meseszerủ egyéni boldogulás látványos példái foglalkoztatják a folyton lemaradókat, a veszteseket. Így nem véletlen az érzés: valamit tenni kell, akár a köz rovására, akár a köz ellenében is.

A szájkosár ma már nem elegáns, hacsak nem mi helyezzük fel, a pórázt ott és akkor használjuk, amikor indokolt (lásd. fenti rendelet), a teret pedig tágítsuk. A határ végtelen. Köztereinket, parkjainkat, vizeinket, környezetünket féltett kincsként óvjuk és ápoljuk, s ennek a jövőbe mutató gondoskodásnak csak járulékos - de nélkülözhetetlen - eszköze a jogi szabályozás. Belátásunk, megértésünk legfőbb bizonyítéka nem a rendelet áthágása, hiszen könnyen megtehetnénk, hanem betartása.

\footnotetext{
${ }^{3}$ Rosen, Harvey S.. Public Finance, 7., McGraw-Hill. (2005)
} 